\title{
Familial Hyperaldosteronism Type 1
}

National Cancer Institute

\section{Source}

National Cancer Institute. Familial Hyperaldosteronism Type 1. NCI Thesaurus. Code C127161.

Familial hyperaldosteronism caused by a chimeric gene containing regions of CYP11B1 and CYP11B2. This condition is responsive to exogenous glucocorticoids. 